LIQUID PHASE METHANOL LAPORTE PROCESS DEVELOPMENT UNIT:

MODIFICATION, OPERATION, AND SUPPORT STUDIES

Quarterly Technical Progress Report No. 16

For The Period 1 April - 30 June 1991

$\mathrm{DOE} / \mathrm{PC} / 90005--\mathrm{T} 55$

DE92 008700

Contractor

AIR PRODUCTS AND CHEMICALS, INC.

Allentown, PA 18195

and

Subcontractor to Air Products

CHEM SYSTEMS INC.

Tarrytown, NY 10591

D. M. Brown - Air Products Program Marager

M. E. Frank - Chem Systems Program Manager

6 August 1991

Prepared for the United States Department of Energy Under Contract No. DE-AC22-87PC90005

Contract Period 9 April 1987 - 31 October 1991 


\section{DISCLAIMER}

This report was prepared as an account of work sponsored by the United States Department of Energy. Nelther the Unlted States nor the United States Department of Energy, nor any of their employees, makes any warranty, express or implied, or assumes any legal liablilty for the accuracy, completeness, or usefulness of any information, apparatus, product or process disclosed, or represents that its use would not infringe privately owned rights. Reference herein to any specific commerclal product, process, or service by trade name, mark, manufacturer, or otherwise, does not necessarlly constitute or imply its endorsement, recommendation, or favoring by the United States Government or any agency thereof. The vlews and opinions of authors expressed herein do not necessarlly state or reflect those of the United States Government or any agency thereof. 


\author{
LIQUID PHASE METHANOL PROCESS DEVELOPMENT UNIT: \\ MODIFICATION, OPERATION, AND SUPPORT STUOIES \\ Quarterly Technical Progress Report \\ Apri1-.June 1991
}

\title{
CONTRACT OBJECTIVES:
}

The objectives of this program are to implement and test the process improvements identified through the engineering studies of the current program (Contract DE-AC22-85PC80007), to demonstrate the capability of long-term catalyst activity maintenance, and to perform process and design engineering work that can be applied to a scaled-up Liquid Phase Methanol (LPMEOH) facility. An optional series of Process Development Unit (PDU) runs is offered to extend the testing of the process improvements. A parallel research program will be performed to enhance the LPMEOH technical data base to improve the likelihood of commercialization of the LPMEOH process.

\section{QUARTERLY SUMMARY:}

- All topical reports describing LaPorte PDU operations have now been submitted to DOE for comment.

- All topical reports describing the R\&D program have now been submitted to the DOE for comment. A draft memo for Task 3.3, Slurry storage and Improved In--situ Catalyst Activation, was completed and issued to DOE for comment.

- A detailed report of the engineering design work done from October 1989 to November 1990, and the Final Project Report are the only outstanding deliverables under the contract.

\section{EUTURE PLANS:}

- Complete reporting requirements, including Final Report.

\section{RESULTS AND DISCUSSION:}

Tasks 1 through 4 are complete.

Task 5 - Air Products Management Activities

- Are essentially complete.

- See Summary for details.

OPEN ITEMS

None

\section{ATTACHMENTS}

The Milestone Schedule Status Report and lilestone Log for the period 1 April - 30 June 1991 are submitted heren ith. 
Page 1 of ?

MILESTONE $1 O G$

Report Date: 6 August 1991

Contract NO. DE-AC22-87PC90005

Ident.

No.-

1.1 Laporte PDU Engineering

1.2 LaPorte PDU Modification

2.1 LaPorte PDU Shakedown

2.2/2.3 LaPorte PDU Operations
Planned

Completion

Date

30 Nov 90

3 Jun 88

15 Aug 88

3 Mar 89
Actual

Completion Date

30 Nov 90

15 Jun 88 Work Completed

13 Jul 88 Work Completed

28 Jul 88 Run E-5 Completed

1 Sept 88 Run E-6 Completed

9 Jan 89 Run E-7 Completed

28 Feb 89 Run E-8 Completed

31 Mar 89

31 Mar 91

LaPorte PDU Deactivation \& Disposal

3.1

Alternate Liquid Media Studies

$18 \operatorname{Mar} 88$

$25 \mathrm{Mar}$

88

Work Completed

3.2

Effects of $\mathrm{CO}_{2}$ in

30 Sept 88

30 Sept 88 Work Completed CO-Rich syngas

3.3

In-Situ Reduction, Simp1 iquefication, Optimiza- 28 Oct 88

15 Mar 89 Report Needed tion \& Slurry Storage 1 Mar 89

3.4 Catalyst Poisons Studies 16 Sept 8819 Aug 88 Work Completed

Fundamental Modeling

30 Apr 90

30 Apr 90 Work Completed *

3.6 Catalyst 
